\title{
Pemetaan Karakteristik Wilayah Demam Berdarah Dengue di Kabupaten Gunungkidul, Provinsi Daerah Istimewa Yogyakarta, Tahun 2011-2015
}

\author{
THE MAPPING OF DENGUE HAEMORRHAGIC FEVER CHARACTERISTIC AREA IN GUNUNG \\ KIDUL REGENCY, DAERAH ISTIMEWA YOGYAKARTA PROVINCE 2011-2015
}

\author{
Nungki Hapsari Suryaningtyas*, Milana Salim, dan Indah Margarethy \\ Balai Litbang Kesehatan Baturaja, Badan Litbang Kesehatan, Kementerian Kesehatan RI \\ Jl. Jenderal Ahmad Yani Km.7 Kemelak, Baturaja, Sumatera Selatan, Indonesia 32111 \\ *Email : nungkihapsari36@gmail.com
}

Submitted: 27-02-2019, Revised:14-07-2019, Revised:07-08-2019, Accepted : 19-08-2019

\begin{abstract}
Dengue Haemorrhagic Fever (DHF) is one of Arthropod-Borne Virus that causes health problems. One of the provinces that have morbidity rates above the national rates was DI Yogyakarta province, about 167.89 per 100.000 population, the number of dengue cases in 2015 in Gunungkidul Regency was 498 cases with three death cases. The study of DHF cases distribution in Gunungkidul Regency was aimed to analyze the spatial risk factors againts DHF cases in Gunungkidul Regency using geographic information system applications. This study used a secondary data sourced from the book of Profile of Gunugkidul District Health Office and the report of Gunungkidul Regency Central Bureau of Statistics in 2011-2015. The variables analyzed included the data of DHF cases per sub-district, population density, the large area, and clean water facilities with rain storage. The data served in map, each variable processed by overlaying methode using the Gis Arc program 10. The mapping results showed that the population density and large area have no effect to the incidence of DHF. All sub-districs in Gunungkidul Regency have the same risk in spreading dengue cases. Most of endemic subsdistrict area have rain storage, that means there are possibility of Aedes aegypti and Aedes albopictus as DHF vector could thrive well in those area.
\end{abstract}

Keywords: DHF, mapping, regional characteristics, Gunungkidul

\begin{abstract}
Abstrak
Demam Berdarah Dengue (DBD) merupakan salah satu penyakit virus tular vektor yang menimbulkan masalah kesehatan. Salah satu provinsi dengan angka kesakitan di atas angka nasional adalah Provinsi Daerah Istimewa Yogyakarta (DIY) dengan angka kesakitan sebesar 167,89 per 100.000 penduduk, jumlah kasus DBD pada tahun 2015 di Kabupaten Gunungkidul (498 kasus) dengan tiga kematian. Kajian mengenai distribusi kasus DBD di Kabupaten Gunungkidul bertujuan untuk menganalisis faktor risiko secara spasial yang berpengaruh terhadap kejadian DBD di Kabupaten Gunungkidul menggunakan aplikasi sistem informasi geografis. Kajian ini menggunakan data sekunder yang bersumber dari buku Profil Dinas Kesehatan Kabupaten Gunugkidul dan laporan Badan Pusat Statistik Kabupaten Gunungkidul tahun 2011-2015. Variabel yang dianalisis meliputi data kasus DBD per kecamatan, kepadatan penduduk, luas wilayah, dan sarana air bersih dengan penampungan air hujan. Data disajikan dalam bentuk peta, setiap variabel disusun dengan metode overlay menggunakan program Arc Gis 10. Hasil pemetaan menunjukkan bahwa kepadatan penduduk dan luas wilayah tidak berpengaruh pada kejadian DBD. Semua kecamatan di Kabupaten Gunungkidul memiliki risiko yang sama dalam penyebaran kasus DBD. Sebagian besar Kecamatan yang endemis DBD memiliki tempat penampungan air hujan, artinya ada kemungkinan vektor DBD, baik Ae. aegypti maupun Ae.albopictus dapat berkembang baik di wilayah tersebut.
\end{abstract}

Kata kunci : DBD, pemetaan, karakteristik wilayah, Gunungkidul 


\section{PENDAHULUAN}

Demam Berdarah Dengue (DBD) merupakan salah satu penyakit vector borne virus yang menimbulkan masalah kesehatan. Angka kesakitan DBD secara nasional pada tahun 2016 meningkat dari tahun 2015, yaitu 50,75 menjadi 78,85 per 100.000 penduduk. ${ }^{1}$ Kenaikan angka kesakitan DBD pada tahun 2016 juga diiringi oleh peningkatan jumlah kabupaten/kota terjangkit DBD dari tahun 2015 terdapat 446 menjadi 463 kabupaten/kota. ${ }^{1}$

Salah satu provinsi dengan angka kesakitan di atas nasional adalah Provinsi Daerah Istimewa Yogyakarta dengan angka kesakitan sebesar 167,89 per 100.000 penduduk. ${ }^{1}$ Jumlah Kasus DBD di Provinsi Daerah Istimewa Yogyakarta tersebar di seluruh kabupaten/kota antara lain pada tahun 2015 tercatat di Kabupaten Kulon Progo (122 kasus) dan tidak ada kematian, Kota Yogyakarta (196 kasus) dengan 13 kematian, Bantul (1.441 kasus) dengan empat kematian, Sleman (520 kasus) dengan sembilan kematian dan Gunungkidul (498 kasus) dengan tiga kematian. ${ }^{2}$

Kabupaten Gunungkidul merupakan salah satu wilayah di Provinsi Daerah Istimewa Yogyakarta dengan karakteristik tipologi yang unik yaitu berupa kawasan perbukitan batu gamping dan bentang karst tandus. ${ }^{3}$ Daerah ini terbagi menjadi tiga zonasi berdasarkan kondisi topografinya, yaitu Zona Utara, Zona Tengah dan Zona Selatan. Kasus DBD telah terjadi di seluruh zona wilayah zona tersebut. ${ }^{4,5}$ Zona Utara, meliputi Kecamatan Patuk, Gedangsari, Nglipar, Ngawen, Semin dan Ponjong bagian utara. Zona Tengah, meliputi Kecamatan Playen, Wonosari, Karangmojo, Ponjong bagian tengah dan Semanu bagian utara. Zona Selatan, meliputi Kecamatan Saptosari, Paliyan, Girisubo, Tanjungsari, Tepus, Rongkop, Purwosari, Panggang, Ponjong bagian selatan dan Semanu bagian selatan. Pembagian ketiga zona tersebut meliputi perbedaan ketinggian dan ketersediaan air di permukaan tanah.

Adanya perbedaan geografis pada tiap zona akan mempengaruhi epidemiologi kasus DBD. Peningkatan kasus DBD dapat diakibatkan karena mobilisasi dan tingkat kepadatan penduduk, sistem transportasi antar wilayah yang semakin baik, pembukaan pemukiman baru serta kurangnya kesadaran dan partisipasi masyarakat dalam memberantas sarang nyamuk. ${ }^{6}$ Faktor lain yang menyebabkan tingginya kepadatan populasi nyamuk Aedes aegypti adalah kecenderungan masyarakat untuk menyimpan air sebagai akibat sulitnya mengakses air bersih. Kontainer atau tempat penampungan air yang menyimpan air dalam periode waktu lama menjadi habitat ideal bagi nyamuk untuk berkembang biak. ${ }^{7}$

Karakteristik wilayah yang tandus menyebabkan sebagian besar wilayah di Kabupaten Gunungkidul mempunyai permasalahan pada ketersediaan air bersih. Salah satu upaya yang dilakukan masyarakat untuk memenuhi kebutuhan air bersih adalah membuat penampungan air hujan untuk kebutuhan seharihari Hasil penelitian yang dilakukan Santoso mendapatkan proporsi sumber air yang paling banyak ditemukan jentik Ae.aegypti adalah sumber air yang berasal dari air hujan. ${ }^{8}$ Kajian mengenai pemetaan kasus DBD di Kabupaten Gunungkidul bertujuan untuk menganalisis faktor risiko spasial yang berpengaruh terhadap kejadian DBD di Kabupaten Gunungkidul menggunakan aplikasi sistem informasi geografis.

\section{BAHAN DAN METODE}

Kajian mengenai pemetaan karakteristik wilayah DBD ini dilakukan di Kabupaten Gunungkidul dengan menggunakan data sekunder yang berasal dariProfil Dinas KesehatanKabupaten Gunugkidul dan Badan Pusat Statistik Kabupaten Gunungkidul. Unit analisis dalam kajian ini adalah wilayah administrasi kecamatan yaitu sebanyak 18 kecamatan yang ada di Kabupaten Gunungkidul. Variabel yang dianalisis meliputi data kasus DBD per kecamatan, kepadatan penduduk, luas wilayah dan sarana air bersih dengan penampungan air hujan. Analisis dilakukan berdasarkan data tahun 2011-2015.

Stratifikasi kecamatan berdasarkan kasus DBD dibagi menjadi 4:

1. Kecamatan endemis yaitu kecamatan yang dalam waktu tiga tahun terakhir ditemukan kasus pada setiap tahunnya.

2. Kecamatan sporadis adalah kecamatan yang dalam tiga tahun terakhir ditemukan kasus tetapi tidak setiap tahun. 
3. Kecamatan potensial adalah kecamatan yang dalam tiga tahun terakhir tidak pernah ada penderita DBD, tetapi penduduknya padat, mempunyai hubungan transportasi yang ramai dengan wilayah lain dan persentase rumah yang ditemukan jentik lebih atau sama dengan $5 \%$.

4. Kecamatan bebas adalah kecamatan yang dalam tiga tahun terakhir tidak pernah ada penderita DBD dan persentase rumah yang ditemukan jentik kurang dari 5\%.

Klasifikasi kepadatan penduduk terbagi menjadi ${ }^{9}$ :

a. $<400$ jiwa $/ \mathrm{km}^{2}$ dalam kategori kepadatan rendah

b. 400-600 jiwa $/ \mathrm{km}^{2}$ dalam kategori kepadatan sedang

c. $600-1000$ jiwa $/ \mathrm{km}^{2}$ dalam kategori kepadatan tinggi

d. $>1000$ jiwa $/ \mathrm{km}^{2}$ dalam kategori kepadatan sangat tinggi

Data luas wilayah dibedakan menjadi empat kelas yaitu ${ }^{9}$ :

a. Wilayah dengan luas wilayah $<70 \mathrm{~km}^{2}$ b. Wilayah dengan luas wilayah $70-85 \mathrm{~km}^{2}$

c. Wilayah dengan luas wilayah $86-100 \mathrm{~km}^{2}$

d. Wilayah dengan luas wilayah $>100 \mathrm{~km}^{2}$

Sedangkan data tentang ketersediaan sarana air bersih dengan penampungan air hujan dibedakan menjadi ada dan tidak ada.

Peta rupa bumi diperoleh dari Bappeda Daerah Istimewa Yogyakarta dengan skala 1: 25.000. Data diolah dan dianalisis dengan melakukan pemetaan pada setiap variabel secara overlay data/tumpang susun menggunakan program Arc Gis 10.

\section{HASIL}

Sebaran kasus mulai tahun 2011-2015 bervariasi di 18 kecamatan yang ada di Kabupaten Gunungkidul. Kecamatan Wonosari menduduki peringkat tertinggi mulai tahun 2012 sampai dengan 2015, meskipun angka kasus pada tahun 2015 menurun dibandingkan tahun 2014. Pola kenaikan per tahun juga terlihat pada Kecamatan Semanu, Playen, dan Nglipar, sedangkan pada Kec. Tanjungsari lonjakan kasus terlihat di tahun 2015 dibandingkan tahun-tahun sebelumnya (Gambar 1).

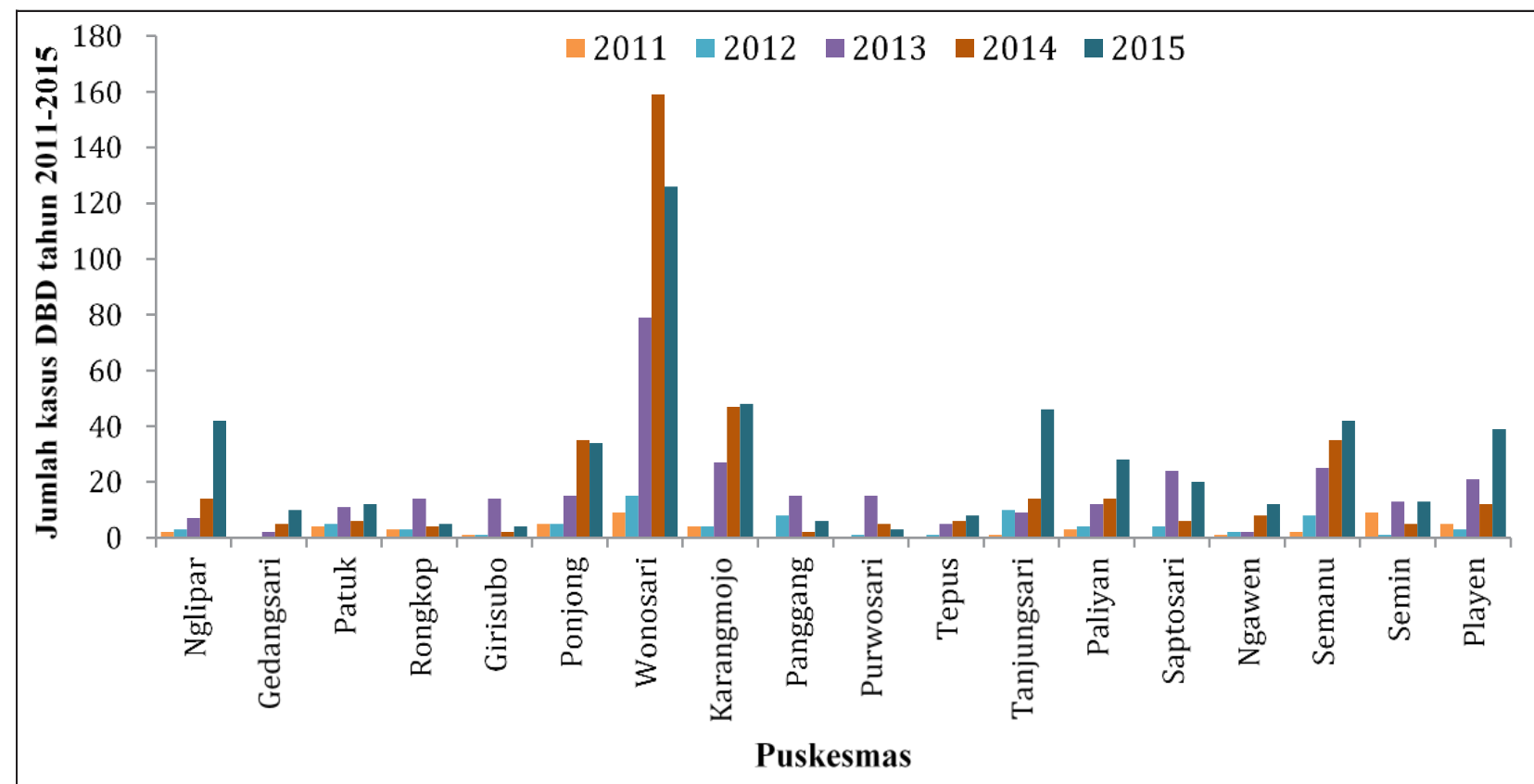

Gambar 1. Jumlah kasus DBD berdasarkan Wilayah Puskesmas di Kabupaten Gunungkidul Tahun 2011-2015 


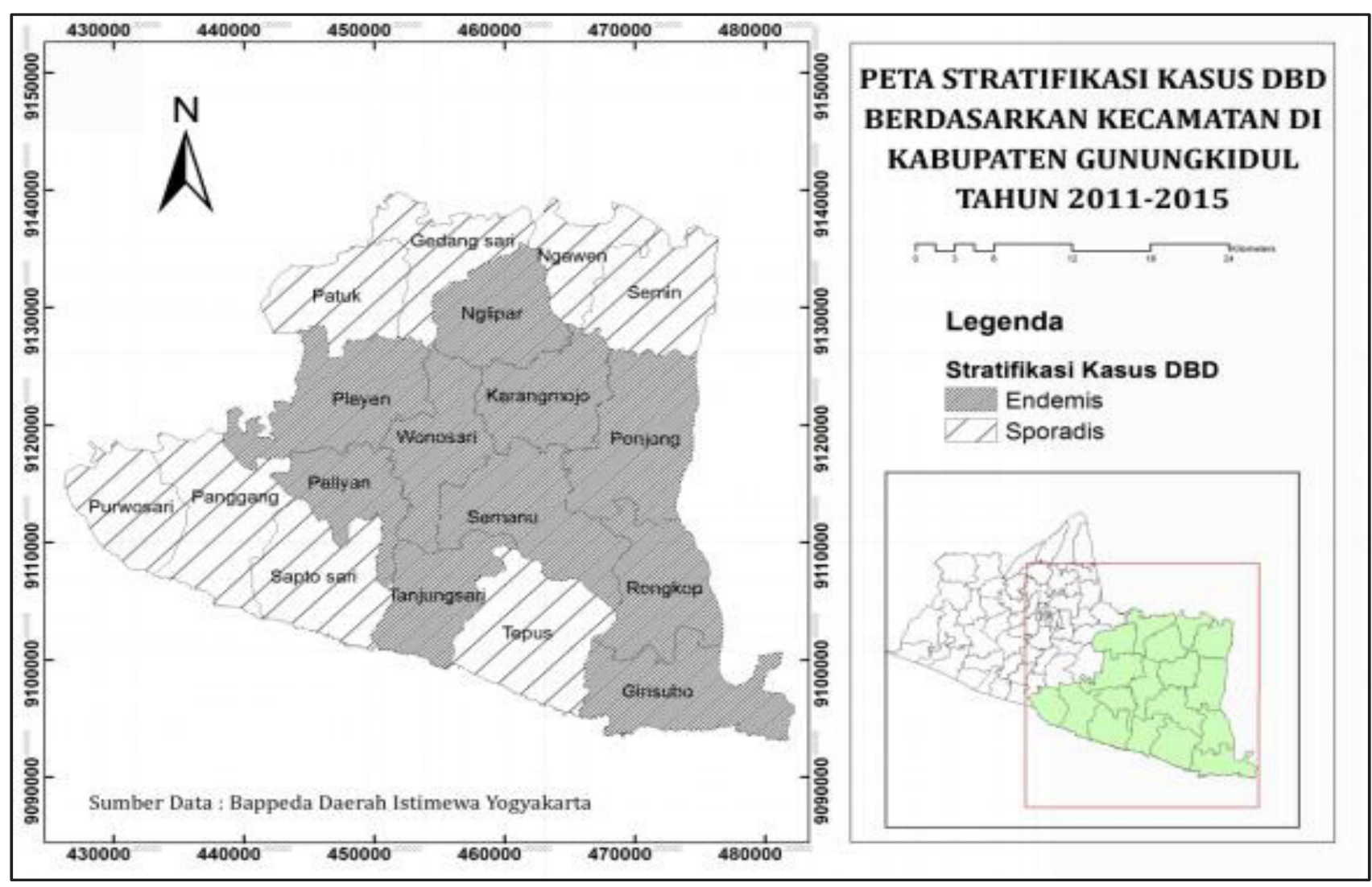

Gambar 2. Peta Stratifikasi Kasus DBD berdasarkan Kecamatan di Kabupaten Gunungkidul Tahun 2011-2015

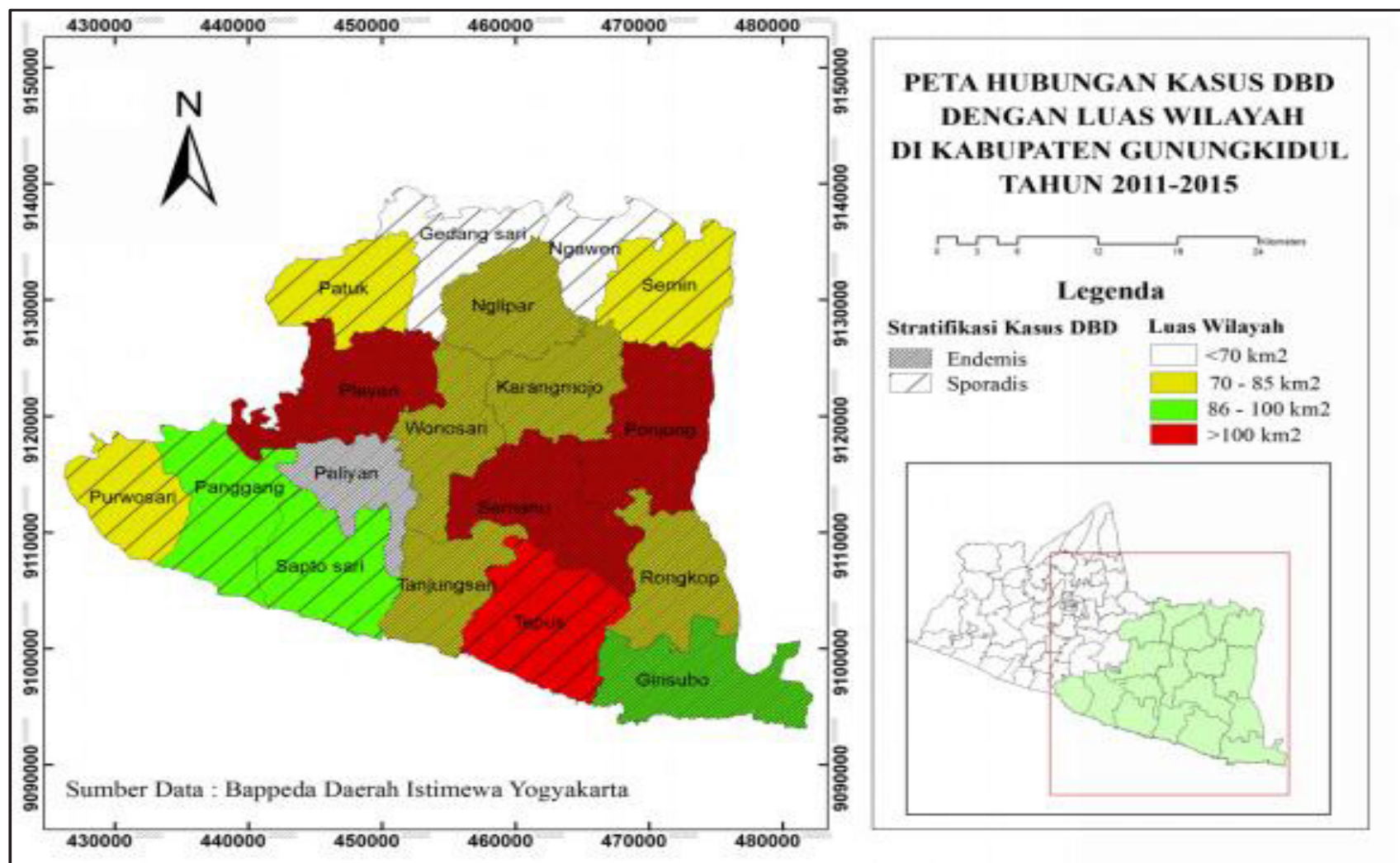

Gambar 3. Peta Hubungan Kasus DBD dengan Luas Wilayah berdasarkan Kecamatan di Kabupaten Gunungkidul Tahun 2011-2015 


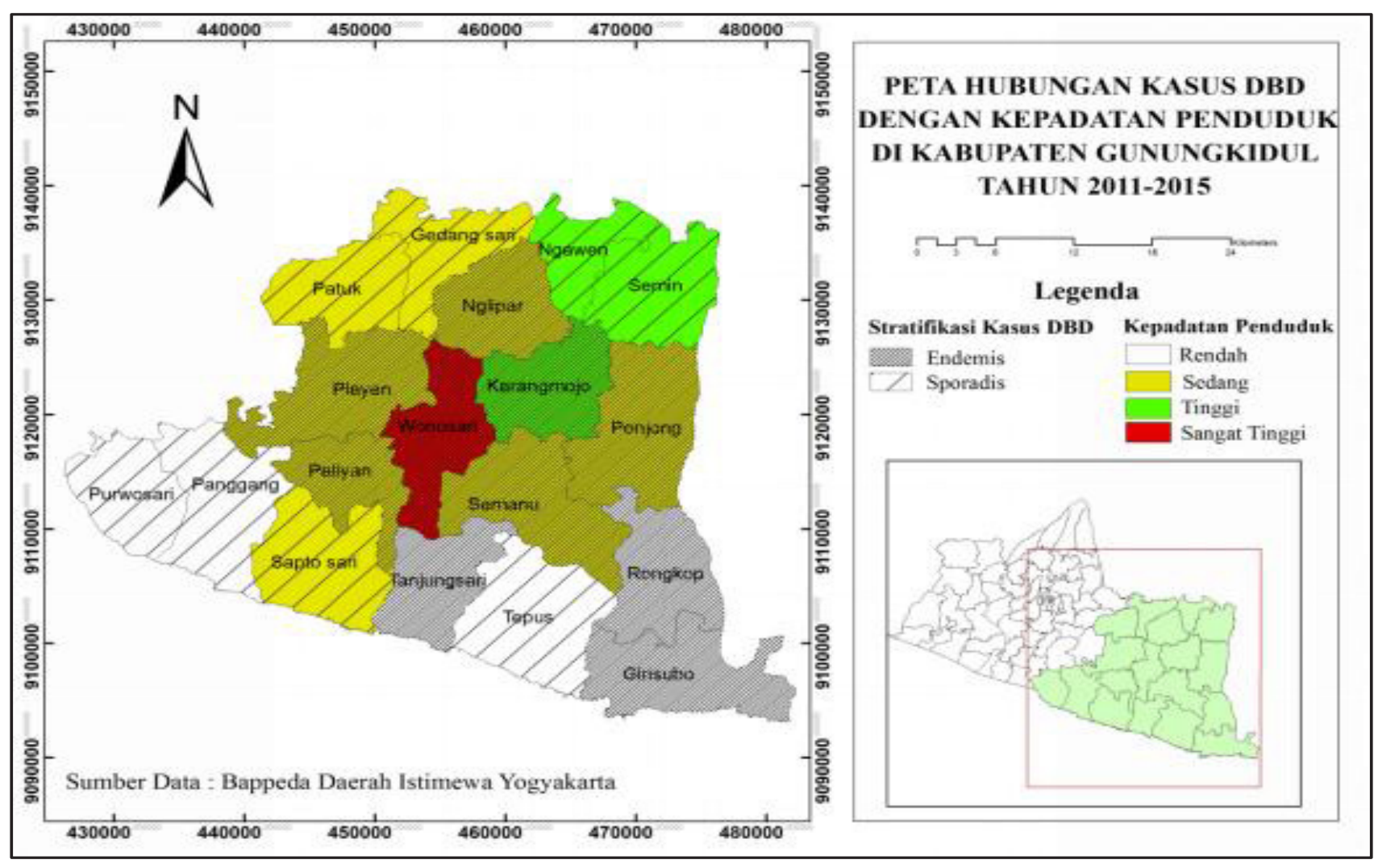

Gambar 4. Peta Hubungan Kasus DBD dengan Kepadatan Penduduk berdasarkan Kecamatan di Kabupaten Gunungkidul Tahun 2011-2015

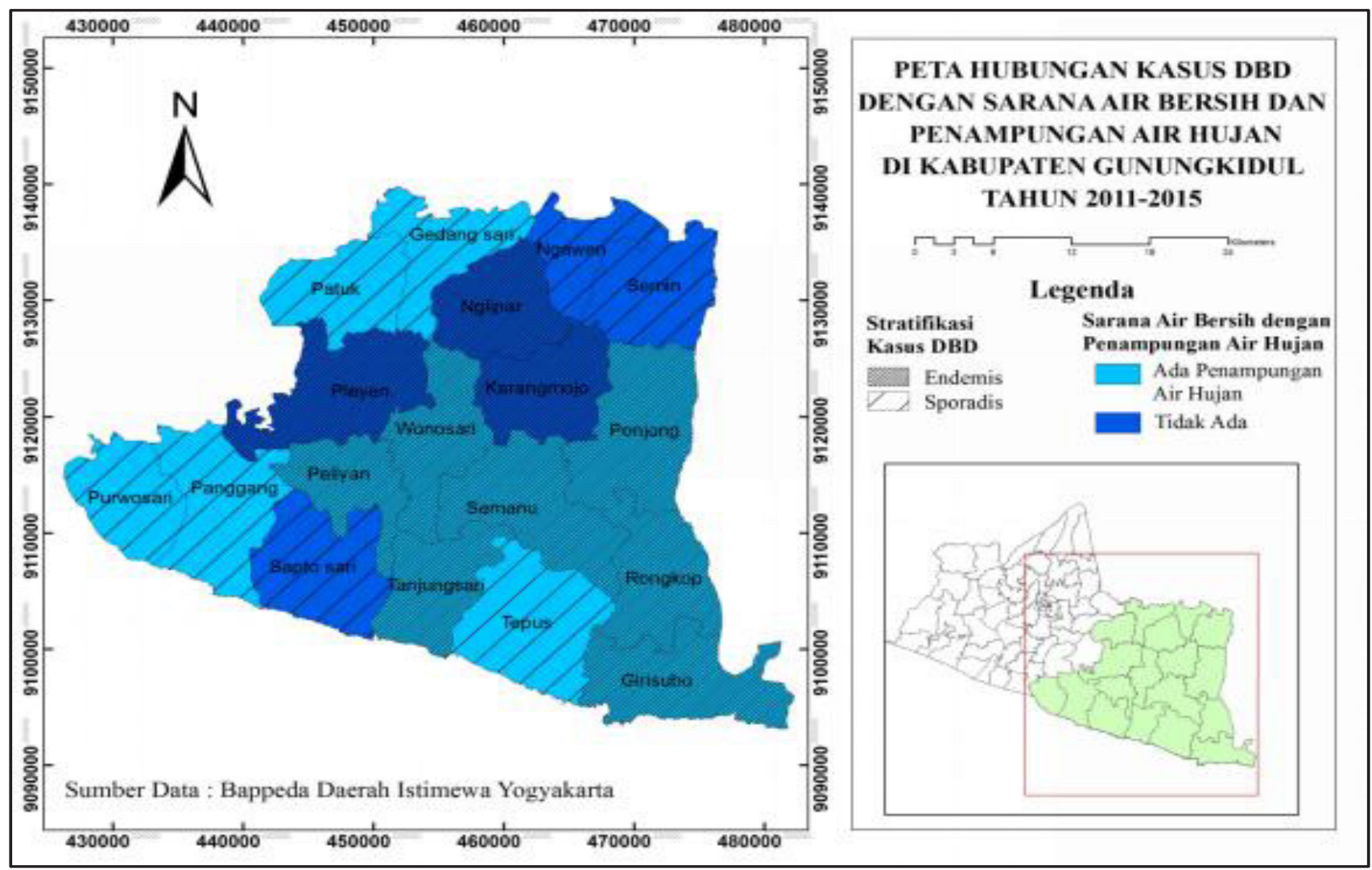

Gambar 5. Peta Hubungan Kasus DBD dengan Sarana Air Bersih dan Penampungan Air Hujan berdasarkan Kecamatan di Kabupaten Gunungkidul Tahun 2011-2015 
Pada Gambar 2 terlihat sebaran wilayah kasus DBD yang berada pada strata sporadik banyak terdapat di bagian utara dan selatan Gunung Kidul, sedangkan daerah endemis lebih terkumpul di zona tengah. Wilayah utara berada pada ketinggian 200-700 meter di atas permukaan laut,wilayah selatan berada pada 0-300 meter di atas permukaan laut dan zona tengah umumnya berada pada ketinggian 150-200 meter di atas permukaan laut.

Berdasarkan luas wilayah, terdapat tiga kecamatan dengan luas wilayah $<70 \mathrm{~km}^{2}$, salah satunya adalah Paliyan yang masuk ke dalam kategori endemis. Luas wilayah $>100 \mathrm{~km}^{2}$ yakni Kecamatan Playen, Semanu, Ponjong yang merupakan wilayah endemis dan Tepus yang tergolong sporadis, sedangkan kecamatan lain masuk dalam kategori luas wilayah $70-100 \mathrm{~km}^{2}$ (Gambar 3).

Berdasarkan kepadatan penduduk terlihat untuk wilayah dengan kepadatan rendah tersebar di enam kecamatan dengan kategori endemis berada di 3 kecamatan yaitu Kecamatan Tanjungsari, Rongkop dan Girisubo serta kategori sporadis berada di Kecamatan Purwosari, Panggang dan Tepus. Kepadatan penduduk sedang tersebar di delapan kecamatan dengan kategori endemis berada di lima kecamatan (Playen, Paliyan, Nglipar, Semanu dan Ponjong), sedangkan untuk kategori sporadis terdapat di tiga kecamatan yaitu Saptosari, Patuk dan Gedangsari. Wilayah dengan kepadatan tinggi terbagi menjadi kecamatan endemis di Kecamatan Karangmojo dan dua kecamatan sporadis di Kecamatan Ngawen dan Semin. Kecamatan Wonosari memiliki kepadatan penduduk sangat tinggi dan tergolong endemis DBD. Hasil menunjukkan bahwa wilayah dengan kepadatan penduduk yang sedang memiliki daerah endemis yang lebih banyak (Gambar 4).

Ketersediaan sarana air bersih dengan penampungan air hujan terlihat bahwa sebagian besar kecamatan memiliki penampungan air hujan sebagai sarana penyimpanan air untuk keperluan penduduk. Dari sepuluh wilayah endemis, tujuh diantaranya memiliki penampung air hujan. Kecenderungan kecamatan yang memiliki sarana air bersih dengan penampungan air hujan memiliki daerah endemis yang lebih banyak dibandingkan dengan kecamatan yang tidak terdapat penampungan air hujan.

\section{PEMBAHASAN}

Pola kasus DBD di wilayah Kabupaten Gunungkidul dari tahun 2011 sampai dengan 2015 cenderung terjadi peningkatan, khususnya pada tahun 2014 ke tahun 2015, meskipun ada beberapa wilayah kecamatan yang menunjukkan penurunan namun tetap menjadi daerah terendemis di wilayah Kabupaten Gunungkidul, yaitu Kecamatan Wonosari. Pola distribusi kasus DBD di Kabupaten Gunungkidul terjadi secara mengelompok atau terdapat clustering kejadian kasus demam DBD atau daerah endemis, yaitu terkumpul pada zona tengah.

Kecamatan Wonosari merupakan wilayah yang terpusat di zona tengah dengan kejadian kasus DBD tertinggi dibandingkan wilayah disekelilingnya dari tahun 2011 sampai dengan 2015, dan kemudian selalu diikuti tingginya kejadian DBD pada wilayah disekeliling Kecamatan Wonosari, seperti Semanu, Karangmojo, Playen, Paliyan, Nglipar, dan Karangmojo. Kejadian kasus DBD di Kabupaten Gunungkidul juga telah menyebar pada zona selatan, seperti wilayah Kecamatan Tanjungsari, Ponjong, Rengkop, dan Girisubo. Artinya ada beberapa faktor yang menyebabkan penyebaran kasus DBD meluas di kabupaten ini.

Populasi penduduk yang semakin padat akan menyebabkan kepadatan tempat tinggal pada daerah tersebut. Hal ini menyebabkan jarak terbang vektor penyakit DBD menjadi lebih pendek sehingga penularannya semakin mudah dan menciptakan kondisi yang tepat untuk transmisi ${ }^{10}$, ini tergambar pada Kecamatan Wonosari yang memiliki kasus DBD tertinggi dengan kepadatan penduduk yang sangat tinggi, dengan tingkat kepadatan penduduk tersebut menjadi salah satu faktor mempermudah terjadi transmisi di wilayah di sekitar Wonosari, salah satunya Karangmojo yang juga memiliki kepadatan penduduk yang tinggi. Kepadatan penduduk dikaitkan dengan jarak terbang nyamuk dan penularan DBD, hal ini disebabkan karena semakin padat penduduk maka semakin 
mudah untuk terjadinya penularan DBD karena jarak terbang nyamuk Aedes merupakan nyamuk yang jarak terbangnya pendek yaitu 50-100 m. ${ }^{11,12}$

Rumah penduduk yang saling berdekatan memudahkan nyamuk berpindah dari satu rumah ke rumah lain sehingga tetangga yang paling dekat memiliki risiko lebih besar tertular DBD, hal ini sejalan dengan hasil penelitian di Kabupaten Demak bahwa kepadatan penduduk berhubungan dengan kejadian DBD. ${ }^{12}$ Kewaspadaan DBD harus ditingkatkan pada wilayah dataran rendah terutama dengan kepadatan penduduk dan kepadatan rumah yang tinggi. ${ }^{13}$ Perlu diwaspadai terjadinya peningkatan kasus pada wilayah yang memiliki kepadatan penduduk sedang bahkan rendah seperti Tanjungsari yang memiliki kasus DBD cukup tinggi, adanya kemungkinan bahwa kasus DBD tersebar pada wilayah perbatasan yang mempermudah transmisi DBD antar wilayah. Mobilisasi penduduk yang tinggi dan didukung oleh transportasi yang baik memudahkan terjadinya penyebaran penyakit, baik yang terbawa kendaraan maupun penduduk yang telah terinfeksi virus yang ditularkan nyamuk DBD. ${ }^{12}$

Penelitian Pei-Chih $\mathrm{Wu}$ menjelaskan bahwa migrasi, aktivitas perdagangan dan berpergian antar wilayah meningkatkan kejadian DBD dan pola penularan. ${ }^{14}$ Begitu juga dengan Sunaryo menjelaskan bahwa mobilitas penduduk dari satu tempat ke tempat lainnya dan biasanya penyakit menjalar dimulai dari suatu pusat sumber penularan kemudian mengikuti lalu lintas penduduk. Makin ramai lalu lintas itu, makin besar kemungkinan penyebaran. ${ }^{12}$ Jika dilihat dari luas wilayah, penyebaran kasus DBD di Kabupaten Gunungkidul menyebar merata baik di wilayah yang $<70 \mathrm{~km}^{2}, 70-100 \mathrm{~km}^{2}$, bahkan di wilayah yang $>100 \mathrm{~km}^{2}$, dan semua klasifikasi tersebut memiliki peluang terjadinya kasus DBD.

Ketinggian merupakan faktor yang penting untuk membatasi penyebaran nyamuk. Beberapa sumber menyebutkan bahwa populasi Ae.aegypti dapat tumbuh dan berkembang dengan optimal apabila berada pada ketinggian dibawah 1.000 meter di atas permukaan laut (mdpl) ${ }^{15,16} \mathrm{di}$ Asia Tenggara Ae.aegypti dapat ditemukan pada ketinggian 1000 mdpl sampai dengan $1.500 \mathrm{mdpl}$, artinya ketinggian 1.000-1.500 mdpl merupakan batas bagi penyebaran Ae.aegypti. ${ }^{17}$ Namun tidak menutup kemungkinan wilayah dengan ketinggian $>1000 \mathrm{~m}$ dpl Ae. aegypti dapat hidup dan berkembang biak karena perubahan suhu yang meningkat akibat pergeseran ekosistem yang disertai degradasi lingkungan sehingga memperluas ruang bagi Ae. aegypti berkembang biak. Jika dilihat dari hasil penelitian ini bahwa wilayah Kabupaten Gunungkidul bagian Utara berada pada ketinggian 200-700 mdpl, wilayah bagian Selatan berada pada ketinggian 0-300 mdpl juga mempunyai peluang tingginya penyebaran dan kehidupan nyamuk Ae. aegypti selain wilayah tengah yang merupakan daerah endemis.

Adanya penampungan air hujan menunjukkan bahwa wilayah Kabupaten Gunungkidul merupakan daerah yang sulit memperoleh air bersih, hal ini sesuai dengan keadaan karakteristik tipologi Gunungkidul yang merupakan kawasan perbukitan batu gamping dan bentang karst tandus. ${ }^{3}$ Kondisi ini mengakibatkan daerah karst mempunyai air permukaan yang sedikit, tidak mempunyai deposit air tanah maupun air sungai yang cukup karena struktur geologi yang didominasi batuan kapur. ${ }^{18}$ Dari sepuluh kecamatan yang endemis DBD di Kabupaten Gunungkidul hanya tiga kecamatan yang tidak memiliki penampungan air hujan, yaitu Playen, Nglipar, dan Karangmojo, selebihnya memiliki tempat penampungan air hujan. Kecamatan Ngawen dan Semin merupakan kecamatan dengan kepadatan penduduk yang tinggiakan tetapi kedua kecamatan tersebut masuk dalam wilayah sporadis. Hal ini dimungkinkan karena tidak adanya penampungan air hujan di wilayah tersebut.Hasil penelitian Santoso, dkk di Kabupaten Ogan Komering Ulu menggambarkan hal yang sama bahwa dengan buruknya kualitas dan kuantitas air bersih mengakibatkan masyarakat pada musim hujan akan menampung air hujan sebagai persediaan air bersih. ${ }^{8}$

Pada umumnya tempat penampungan air hujan tersebut berada di luar rumah, tidak memiliki tutup dan jarang dibersihkan/kuras seperti drum, tedmon, bahkan ember sehingga memungkinkan 
telur nyamuk Aedes menempel pada TPA tersebut. Hal ini menunjukkan adanya potensi keberadaan nyamuk dewasa Aedes yang bersifat eksofolik yang cenderung menyukai berkembang biak di luar tempat tinggal manusia, yaitu $A e$. albopictus. Menurut WHO dalam Prasetyowati, Ae. albopictus berkembangbiak di lubanglubang pohon, drum, bahan bekas yang terdapat di luar (peridomestik). ${ }^{19}$ Pada kejadian wabah demam berdarah dengue (DBD), Ae. albopictus sering dianggap sebagai vektor sekunder sesudah Ae. aegypti, tetapi pada beberapa kasus ledakan DBD, spesies ini dapat berperan sebagai vektor utama, seperti yang pernah terjadi di Burma pada tahun 1975, di Singapura pada tahun 1969 dan di Indonesia pada waktu terjadi wabah di Bantul Yogyakarta tahun 1977, oleh sebab itu spesies ini menjadi salah satu vektor yang potensial bagi penularan dengue. ${ }^{20}$ Hasil penelitian di Kelurahan Sukarami Kota Palembang juga menunjukkan bahwa sebagian besar larva Aedes ditemukan pada kontainer yang terletak di luar rumah. ${ }^{21}$

Adanya perubahan perilaku dari nyamuk Aedes dalam berkembang biak, bukan hanya pada penampungan air bersih yang tidak berhubungan langsung dengan tanah, akan tetapi nyamuk juga dapat beradaptasi dengan kondisi sebaliknya misalnya di dalam pot yang airnya tergenang (bukan alas pot). Larva yang berada dalam air bersih yang mengandung bahan organik dapat tumbuh subur sebagai pemakan di dasar (bottom feeder), sehingga larvasida bentuk granul, seperti abate sangat sesuai membasmi nyamuk ini. ${ }^{22}$

Kepadatan nyamuk Aedes spp sangat berhubungan dengan kejadian DBD, hasil pengumpulan data Rikhus Vektora Tahun 2017 menunjukkan bahwa angka bebas jentik (ABJ) di daerah endemis DBD di Kabupaten Gunungkidul sebesar 59\%. ${ }^{23}$ Berdasarkan Permenkes Nomor 50 Tahun 2017 Tentang Standar Baku Mutu Kesehatan Lingkungan dan Persyaratan Kesehatan untuk Vektor dan Binatang Pembawa Penyakit Serta Pengendaliannya bahwa agar tidak terjadi penularan DBD maka Angka Bebas Jentik (ABJ) di suatu wilayah minimal $95 \% .{ }^{24}$ Ini menunjukkan bahwa kepadatan nyamuk Aedes spp masih sangat tinggi di Kabupaten Gunungkidul. Tingkat kepadatan jentik yang tinggi disebabkan karena masyarakat memiliki perilaku buruk dalam Pemberantasan Sarang Nyamuk (PSN). proposi keberadaan jentik lebih banyak ditemukan pada penduduk yang tidak melakukan PSN sebesar 40,8\%. ${ }^{25}$ Untuk itu perlu ditingkatkan pengetahuan masyarakat tentang PSN.

\section{KESIMPULAN}

Hasil pemetaan menunjukkan bahwa kepadatan penduduk dan luas wilayah tidak berpengaruh pada kejadian DBD. Semua kecamatan di Kabupaten Gunungkidul memiliki risiko yang sama dalam penyebaran kasus DBD. Wilayah dengan sebaran kasus DBD di Kabupaten Gunungkidul terkelompok di wilayah zona tengah dengan kasus tertinggi berada di wilayah Kecamatan Wonosari, dan menyebar ke daerah Selatan. Hal yang harus diperhatikan adalah adanya penyebaran kasus DBD di mana wilayah yang tidak padat penduduknya, yaitu Tanjungsari termasuk daerah yang edemis DBD. Sebagian besar Kecamatan yang endemis DBD memiliki tempat penampungan air hujan yang dapat berpotensi dalam penularan DBD. Oleh karena itu perlu dilakukan sosialisasi kepada masyarakat untuk memantau penampungan air hujan secara berkala.

\section{UCAPAN TERIMA KASIH}

Penulis mengucapkan terima kasih kepada Kepala Balai Litbangkes Baturaja atas kesempatan yang telah diberikan untuk penulisan artikel ini. Ucapan terima kasih kepada Lasbudi P. Ambarita, M.Sc dan Yahya M.Si atas masukan yang diberikan untuk artikel serta semua pihak yang telah membantu terselesainya artikel ini.

Kontribusi penulis pada artikel ini yaitu, kontributor utama: NHS, MS dan IM. NHS bertanggung jawab dalam konsep, analisis data dan metodologi, MS bertanggung jawab penyajian hasil dan IM bertanggung jawab dalam mengkaji hasil.

\section{DAFTAR RUJUKAN}

1. Kementerian Kesehatan Republik Indonesia. Profil Kesehatan Indonesia Tahun 2016. 
Jakarta: Kementerian Kesehatan RI; 2017.

2. Dinas Kesehatan Provinsi DIY. Profil Kesehatan DIY 2015. Yogyakarta: Dinas Kesehatan Provinsi DIY; 2015.

3. Dinas Kesehatan Kabupaten Gunungkidul. Profil Dinas Kesehatan Kabupaten Gunungkidul Tahun 2016. Dinas Kesehatan Kabupaten Gunungkidul; 2016. http://dinkes. gunungkidulkab.go.id/. Diakses pada tanggal 29 Desember 2017.

4. Djati RAP, Santoso B, Satoto TBT. Hubungan Faktor Iklim dengan Demam Berdarah Dengue di Kabupaten Gunung Kidul Tahun 2010. J Ekol Kesehat. 2012;11(3):230-239.

5. Direktorat Jenderal Pengendalian Penyakit dan Penyehat Lingkungan. Modul Pengendalian Demam Berdarah Dengue. Jakarta: Kementerian Kesehatan RI; 2011.

6. Sandy, Semuel; Sasto IH. Demam Berdarah Dengue (DBD) di Kabupaten Keerom Provinsi Papua Tahun 2011-2014. Balaba. 2015;11(1):35-42.

7. Ambarita LP, Sitorus H, Komaria RH. Habitat Aedes Pradewasa dan Indeks Entomologi di 11 Kabupaten / Kota Provinsi Sumatera Selatan. Balaba. 2016;12(2):111-120.

8. Santoso; Taviv Y, Mayasari R, Margarethy I, Dsp IGW. Hubungan Karakteristik Kontainer dengan Keberadaan Jentik Aedes aegypti pada Kejadian Luar Biasa Demam Berdarah Dengue : Studi Kasus di Kabupaten Ogan Komering Ulu. J Vektor Penyakit. 2018;12(1):9-18.

9. BadanPusatStatistik Kabupaten Gunungkidul. Kabupaten Gunungkidul Dalam Angka 2016. Gunungkidul: BPS Kabupaten Gunungkidul; 2016.; 2016.

10. Setyaningsih W, Setyawan DA. Pemodelan Sistem Informasi Geografis (SIG) Pada Distribusi Penyakit Demam Berdarah Dengue (DBD) di Kecamatan Karangmalang Kabupaten Sragen. J Terpadu Ilmu Kesehat. 2014;3(2):209-214.

11. Masrizal, Sari NP. Analisis Kasus DBD Berdasarkan Unsur Iklim dan Kepadatan Penduduk Melalui Pendekatan GIS di Tanah Datar. J Kesehat Masy Andalas. 2016;10(2):166-171.

12. Farahiyah M, Nurjazuli, Setiani O. Analisis spasial faktor lingkungan dan kejadian DBD di Kabupaten Demak. Bul Penelit Kesehat. 2014;42(1):25-36.

13. Ikawati B. Aspek Kekinian tentang Penelitian Demam Berdarah Dengue di Pulau Jawa dan Sekitarnya. Balaba. 2018;14(1):85-94.

14. Pei-Chih Wu, Jinn-Guey Lay, How-Ran Guo, Chuan-Yao Lin, Shih-Chun Lung H-JS. Higher temperature and urbanization affect the spatial pattern of dengue fever transmission in subtropical Taiwan. Sci Total Environ. 2009;407:2224-2233.

15. Lukmanjaya G, Martini, Hestiningsih R. Kepadatan Aedes spp Berdasarkan Ketinggian Tempat di Kabupaten Wonosobo. J Kesehat Masy. 2012;1(2):338-345.

16. Hodijah DN, Prasetyowatil H, Marina R. Tempat Perkembangbiakan Aedes SPP. Sebagai Penular Virus Dengue Pada Berbagai Tempat di Kota Sukabumi. J Ekol Kesehat. 2015;14(1):1-7.

17. Sofiyatun E, Sunarno JM, Hanayanti O, Wibowo S. Makala Prosiding Seminar Nasional Rumusan Strategi Kesehatan dan Pertanian Dalam Percepatan Pengentasan Kemiskinan Menuju Tercapainya MDGS 2015. In: Ae. Aegypti Stadium Aquatik Pada Tiga Lokasi Ketinggian Di Kabupaten Ciamis. ; 2012:108117.

18. Putri Dwi Yuliyana. Pemanfaatan Air Tanah Dalam Urgensi Kebutuhan Air Daerah Karst Gunungsewu di Gunungkidul, Daerah Istimewah Yogyakarta. Research Gate. 2018;(May):1-9.

19. Prasetyowati H, Marina R, Hodijah DN, Widawati M, Wahono T. Survey Jentik dan Aktivitas Noktural Aedes SPP Di Pasar Wisata Pangandaran. J Ekol Kesehat. 2014;13(1):3342.

20. Boesri H. Biologi dan Peranan Aedes albopictus (Skuse) 1894 sebagai Penular Penyakit. Aspirator. 2011;3(2):117-125.

21. Suryaningtyas NH, Margarethy I, Desy Asyati. Karakteristik Habitat dan Kualitas Air Terhadap Keberadaan Jentik Aedes spp di Kelurahan Sukarami Palembang. Bul Spirakel. 2017;9(2):53-59.

22. T AG, R FB. Analisis Faktor Risiko Kejadian Demam Berdarah. Eksplanasi. 2010;5(2):1-9. 
23. Badan Penelitian dan Pengembangan Kesehatan Kementerian Kesehatan RI. Laporan Akhir Riset Khusus Vektor Dan Reservoir Penyakit Provinsi Daerah Istimewa Yogyakarta Tahun 2017. Jakarta: Badan Litbangkes Kementerian Kesehatan RI; 2017.

24. Lestari E, Sianturi CLJ, Hestiningsih R, Wuryanto MA. Kepadatan Jentik Vektor Demam Berdarah Dengue (DBD) Aedes sp. di Daerah Endemis, Sporadis dan Potensial Kota Semarang Provinsi Jawa Tengah. Balaba. 2014;10(2):71-76.

25. Imawati D ST. Faktor-faktor yang Berhubungan dengan Keberadaaan Jentik di Dusun Mandingan Desa Kebon Agung Kecamatan Imogiri Kabupaten Bantul. J Med Respati. 2015;10(2):78-89. 